\title{
Prospects and Benefits of Ecotourism- oriented Digital Comic as a Literacy Entity in Elementary Schools
}

\author{
${ }^{1}$ Shanta Rezkita, ${ }^{2}$ Heri Maria Zulfiati, ${ }^{3}$ Taryatman, ${ }^{4}$ Abdul Rahim \\ ${ }^{1}$ shanta.rezkita@ustjogja.ac.id, ${ }^{2}$ heri.maria@ustjogja.ac.id, ${ }^{3}$ taryatman@ustjogja.ac.id, \\ ${ }^{4}$ pak_aim@ustjogja.ac.id \\ 1,2,3,4 Universitas Sarjanawiyata Tamansiswa, Yogyakarta, Indonesia
}

\begin{abstract}
Learning success not only depends on the quantity of teaching materials, but also on the ability of educators to design learning resources. Lately, the Adiwiyata elementary school tried to exploit local potentials of the region as learning resources, one of which is ecotourism. Therefore, this study aims to describe the eco-tourism potential of Pancoh Yogyakarta as a source of literacy in the form of digital comics. The research approach used was descriptive qualitative along with the subject of Pancoh ecotourism management, and teachers. The data collection techniques include observation, interview, and documentation using Miles' and Huberman's model techniques to examine the validity of data through the source, technique and time triangulation. The results of the study showed that Pancoh environmental tourism was attractive because of its natural beauty. The interesting thing about this tour is the support of the tourism awareness group (Pokdarwis) or Pancoh through a movement that supports surrounding communities and their economy. The existence of local ecotourism collaboration and technology becomes a potential for the world of education in the digital era. This potential can be realized in the form of digital comics development by utilizing the eco-tourism for elementary school students. Pancoh tourism potentials contain a plethora of content materials for elementary schools' lessons as mandated by the thematic learning in the 2013 curriculum.
\end{abstract}

Keywords: Ecotourism; Digital comics; Literacy; Elementary school

\section{Introduction}

The development of information and communication technology affects $21^{\text {st }}$ century learning patterns. No wonder, the role of the teacher is getting bigger especially the ability in designing learning. The role of teachers is certainly inseparable from other components in the education system. The results of Falis' research [1] emphasize that there are six components involved in the education system, namely policies, curriculum and assessment, pedagogy, ICT, organization and administration, and professional development. Furthermore, teachers are expected to develop technology-based self-competence by focusing on three aspects (technology literacy, mastery of deep knowledge, and knowledge creation).

Technology-based learning is still not optimal, especially at the elementary school level. Even though the ability of people to access internet technology every year has increased. This is reinforced by the 2017 KOMINFO Infographic survey results [2] that the second largest internet user in Indonesia based on the last level of education is a bachelor/ diploma of about $79,23 \%$ after postgraduate and utilized in the field of education for the purposes of reading articles around $55,30 \%$, viewing tutorial videos around $49,67 \%$, educational articles / videos share around $21,73 \%$, online courses around $17,85 \%$, and school lists around $14,63 \%$. This data can be assumed that elementary school-age children do not have access to the internet. Therefore, the teacher as a graduate or graduate can optimize the use of the internet in designing technology-based learning that will be applied to school computers. Some adiwiyata elementary schools in Yogyakarta have been facilitated by computer laboratories so as to enable integrated learning patterns with computer-aided information technology. However, it is necessary to conduct a needs analysis in advance to determine the form of technology that is appropriate for the school. As stated by Hobbs [3] in general, teachers are given the freedom 
to decide the form, time and method of using technology and digital media in classrooms in elementary schools.

$21^{\text {st }}$ century education must be able to combine local and global potential. This means that the presence of technology in the development of sustainable learning does not mean ignoring cultural and social interactions in society. Developing issues in the world are applied in Indonesian education by adjusting the existing culture. For example, the use of ecotourism as a local potential can benefit both students, schools and society. The same thing expressed by Mgonja, Sirima, \& Mkumbo [4] promotion of local ecotourism can provide benefits for local communities, for example improving the economy through new jobs so as to improve a more decent life. In addition, ecotourism also plays a role in preserving the environment through the conservation of ecosystems and maintaining the cultural and spiritual preservation of tourism communities. However, there are challenges that are quite severe for the community if they do not have extensive knowledge about their area. Because it will limit their access to participate in the ecotourism business.

One of the local potentials of Yogyakarta that needs to be preserved and preserved is tourism in Pancoh Hamlet. This hamlet became the Ecotourism Village in 2012 with various potentials such as nature, education, culture and history. Pancoh's natural tourism potential includes natural scenery with the backdrop of Mount Merapi, reservoirs, fish ponds, rivers, salak garden rice fields, flower gardens. Pancoh's educational tourism potential includes making handicrafts (caping art, making batik, handmade from used goods), learning art and culture, planting, caring and picking zalacca, planting, caring and picking flowers, making biogas, hijacking, and fishing. Pancoh's cultural tourism potential includes nyadran, karawitan, laras madyo, bungbeh (children's dolanan). Outbound tourism potential of Pancoh includes river trails and fun games. The historical tourism potential of Pancoh is the existence of the building "Londo" as a historical building of the Dutch heritage. Therefore, Pancoh ecotourism is different from other conventional tourism because it focuses on environmental sustainability and natural resources.

The introduction comes at the start of a piece of writing. It introduces the research by situating it (by giving background), presenting the research problem and saying how and why this problem will be "solved." Without this important information the reader cannot easily understand the more detailed information about the research that comes later in the paper. It also explains why the research is being done (rationale) which is crucial for the reader to understand the significance of the study.

Environmental knowledge is needed by all people. When since elementary school age has good environmental knowledge and is trained in environmental sensitivity, it is expected that the adult can participate in protecting and preserving the environment. But the relationship between knowledge, sensitivity, and environmental behavior is sometimes not in line. This is because one's behavior towards the environment is closely related to the culture and environment of the family, so it takes time to change the behavior. Considered by the results of Nunez \& Clores' research [5] that ecoliteracy of students has three dimensions, namely the integration of environmental attitudes and sensitivity, pro-environmental behavior and environmental knowledge. Students who are more knowledgeable about the environment have strong sensitivity and attitude but do not always have strong pro-environmental behavior. Therefore, it needs an effort to achieve higher knowledge, environmental sensitivity and proenvironmental behavior.

A person's knowledge of the environment can be increased through literacy activities. Samto [6] stressed that in the present context, literacy is not only defined as the ability to read, write, and count. But literacy can be interpreted as literacy of knowledge and technology, 
culture and citizenship, critical thinking, and sensitivity to the surrounding environment. Furthermore literacy in elementary schools is carried out gradually through GLS (School Literacy Movement) [7] namely habituation, development, and learning. Examples of activities in the learning stage that use physical, social affective, and academic environments are accompanied by a variety of literary (print, visual, auditory, digital) readings that are rich in literacy outside of textbooks.

Based on the analysis of the needs of Bhayangkara elementary school, it is known that all students like to study in ecotourism and most students like to read comics. However, the availability of comics that support thematic learning is still limited and there are no comics with environmental themes. Actually, some teachers have tried to utilize technology in learning such as the use of video scripts on water cycle material even though it has not been maximized. The teacher also hopes that there is a comic with a tourism theme that can combine some of the material in thematic learning in accordance with the school's vision and mission. One indicator that supports the achievement of the adiwiyata school's vision is excellence in environmental management, utilization and preservation. Based on these considerations, it is necessary to use ecotourism as a source of student learning in the form of digital comics.

The definition of digital comics varies. Digital comics are defined as comics in the form of a digital format containing images or series of images on panels with certain frames and equipped with word balloons and writing as visual meanings. Besides that comics cannot be pure moving images and pure audio [8]. Digital comics sourced from local potential are expected to preserve the natural, cultural and social environment. Therefore, it is necessary to do a description of the prospects and benefits of Pancoh Yogyakarta ecotourism as a source of literacy for elementary school students in the form of digital comics.

\section{Literature Review}

The use of technology in elementary school classrooms needs to pay attention to the shape and design to be right on target. An article [9] states that there is a significant shift in the setting of time and space when learning uses certain digital compositions. There are various technologies that teachers can use in the classroom. Thus the designed digital design will affect the system and the nature of learning.

The use of web comics by Vassilikopoulou [10] in language learning, was stated that the integration was based on comic needs as visual communication in modern culture, comic needs in students' reading experience, comics had complex cultural characteristics, functional use of comics could be used in various communication situations and in the development of multiliteration skills (linguistic, visual, technological and cultural literacy), and comics are easily found in other media such as newspapers, tales and television. The results show that web comics can be accepted by students in language learning. The comic making process that has been done helps students to be linguistically skilled and able to apply their imagination in making stories with the cultural experiences they have.

The use of the comic book in the study of Richter, Rendigs, \& Maminirina [11] informs that when collaborated with additional material on local conditions in rural Madagascar can improve the environmental knowledge of elementary school students. The improvement can be seen from the acquisition of the highest score of the test within one year after the environmental education ends. The comic book contains the adventures of two girls and two boys at the age of elementary school children consisting of several episodes with a focus on nature conservation on Lake Alaotra ecotourism, Madagascar. With additional material can 
stimulate team work and student group discussions. Comic packaging with eight thematic episodes provides innovative and meaningful learning for students so they know the local potential in environmental education. The acquired environmental knowledge becomes a prerequisite for students to develop positive attitudes that then encourage environmentally friendly behavior.

Indonesia is rich in tourism potential, if the teacher is able to innovate then easily the integration of learning is done in the classroom. Research studies by Sutrisno \& Afendi [12] indicate that the concept of edu-ecotourism can be applied in the Gronggong area and has the potential to become Cirebon tourism. The concept that was developed was the integration of environmental conservation efforts with the design of an environmental space themed education. Thus ecotourism as a learning resource can be packaged with certain technologies. The result is that every student in various regions can recognize the natural, cultural, social, and Indonesian environment.

Based on several studies, it can be interpreted that every form of technology used has advantages and disadvantages. Integrating local potential with technology in classroom learning must analyze the potential of ecotourism and the needs of elementary school students. Therefore, this paper focuses on the description of the ecotourism potential of Pancoh Yogyakarta and its use as a source of literacy for elementary school students in the form of digital comics.

\section{Material \& Methodology}

The research approach used was descriptive qualitative with the subject of Pancoh ecotourism management, and teachers in Adiwiyata Elementary School. Data collection with observation, interview, and documentation techniques was then analyzed using Miles and Huberman model techniques and examined the validity of the data through source, technique and time triangulation.

\section{Results and Discussion}

The results of Pancoh ecotourism observations show that there is a clean river flow, the use of ponds for the community, cultural diversity of the community, community collaboration to improve the economy after the Merapi eruption in 2006. This fact is supported by the results of interviews with tourism managers Pancoh. The development of Pancoh into a Tourism Village is supported by the enthusiasm and motivation of several groups of people who are aware of tourism or known by Pokdarwis, so that currently around $75 \%$ of the Pancoh people want to support and be involved in the development of Tourism Villages. This potential can be used as a story idea in making comics adapted to the elementary school curriculum. That is, a lot of interesting things from Pancoh ecotourism are not limited to its natural attractiveness, but its culture and social community.

The results of interviews with several students obtained by students answered that they liked to study in ecotourism because it made them more familiar with nature and could play. Preferred ecotourism is a place with various types of plants and animals. Besides that, a place that has a river so students can do the river. This is in accordance with the natural conditions of Pancoh which has a spring that flows from Kali Adem. It is located around the slopes of Mount Merapi making the land very fertile, so many agricultural plants that utilize the river flow for irrigation. Even during the dry season, ecotourism in Pancoh does not experience water shortages. 
Meanwhile, related to the environmental theme, almost all students have a concern for clean environmental management. This is indicated by the habit of saving water, caring for class plants, working in school. However, in other aspects students are still confused in distinguishing waste by type. For this reason, the use of media is needed to equip students about environmental knowledge. The use of digital comics is an alternative solution to develop their ability to realize environmental literacy. This can be seen from the results of interviews that around $80 \%$ of students like to read comics. According to them the preferred comics are comics that have the characteristics of peers and are varied. As many as $73 \%$ of students answered comics had been used in the learning process. Meanwhile $40 \%$ of students answered comics often used in the learning process. However, based on teacher interviews, it was found that there were still limited availability of comics in each learning theme. While comics with environmental themes do not fully meet the scope of competence. The teacher hopes that there are comics with tourism themes that can combine several materials, for example with cultural topics and narratives about adventure.

Based on the analysis of curriculum content and teacher interviews, comic media can be used in learning in V class, especially on our friends' environmental themes. The basic competencies of several subjects that make it possible to develop in digital comics are presented in Table 1 below.

Table 1. Basic Competency Mapping of Our Friends Environmental Theme

\begin{tabular}{|c|c|c|}
\hline Subjects & Knowledge & Skills \\
\hline Indonesian & $\begin{array}{l}\text { 3.8 Describes the sequence } \\
\text { of events or actions } \\
\text { contained in nonfiction } \\
\text { texts }\end{array}$ & $\begin{array}{l}\text { 4.8 Represents the event or action } \\
\text { by taking into account the } \\
\text { background of the story } \\
\text { contained in the fictional text }\end{array}$ \\
\hline Natural Sciences & $\begin{array}{l}\text { 3.8 Analyzing the water } \\
\text { cycle and its impact on } \\
\text { events on earth and the } \\
\text { survival of living things }\end{array}$ & $\begin{array}{l}4.8 \text { Making creation on water } \\
\text { cycle schemes based on } \\
\text { information from various } \\
\text { sources }\end{array}$ \\
\hline $\begin{array}{l}\text { Pancasila and civic } \\
\text { education }\end{array}$ & $\begin{array}{l}\text { 3.3 Reviewing the socio- } \\
\text { cultural diversity of the } \\
\text { community }\end{array}$ & $\begin{array}{l}\text { 4.3 Organizing activities that } \\
\text { support the socio-cultural } \\
\text { diversity of the community }\end{array}$ \\
\hline Social Sciences & $\begin{array}{l}\text { 3.3 Analyzing the role of the } \\
\text { economy in efforts to } \\
\text { improve the lives of } \\
\text { people in the social and } \\
\text { cultural fields to } \\
\text { strengthen national unity } \\
\text { and unity. }\end{array}$ & $\begin{array}{l}\text { 4.3 Presenting the results of an } \\
\text { analysis of the role of the } \\
\text { economy in efforts to } \\
\text { improve people's lives in the } \\
\text { social and cultural fields to } \\
\text { strengthen national unity and } \\
\text { unity. }\end{array}$ \\
\hline $\begin{array}{l}\text { Cultural Arts and } \\
\text { Crafts }\end{array}$ & $\begin{array}{l}3.1 \text { Understanding story } \\
\text { pictures }\end{array}$ & 4.1 Making story pictures \\
\hline
\end{tabular}

Utilizing the potential that exists in ecotourism Pancoh in learning can provide a contextual picture through ecoliteracy. Ecoliteration is needed in educational programs that illustrate that between human life and the earth has a strong relationship. Even in the political, social and economic fields in designing sustainable lifestyles. Principles in ecoliteracy can be 
grown through school and outside school education, from kindergartens to universities [13]. Thus, everyone will emerge to realize the environment.

Environmental literacy efforts can be mediated through digital comics so as to create attractive learning for elementary school students. The attractiveness of students towards learning is influenced by the teacher's ability to design media in accordance with the learning objectives, using varied visuals, stimulating curiosity, both intellectually and emotionally. Based on the description above, the form of technology used is digital comics with the help of comic life and flip book software. Aside from being a comic-making tool, comic life can also help teachers in making brochures, learning guides, photo albums and greeting cards. The teacher can arrange the comic page layout with a panel for images and text on the balloon. There is also a filter to convert digital images into various images made by hand so that the comic look is more attractive. In this case, the Pancoh ecotourism prospect is used as a story and picture idea. The comic results with the comic life application are then put into a flip book like powerpoint which resembles a thick book and each page shows comics look like moving.

\section{Conclusion}

Technological development in the $21^{\text {st }}$ century has an impact on the development of learning media in elementary schools. The existence of digital comics can be accessed in various places and times which are very easy to use by teachers to foster the spirit of student literacy. This capability can be developed through technology that is collaborated with local potential areas such as ecotourism. This is done so that students cannot leave the area amid the rapid development of technology.

\section{References}

[1] A. Fallis, "Unesco ICT Competency Framework for Teachers," J. Chem. Inf. Model., vol. 53, no. 9, pp. 1689-1699, 2013.

[2] Kominfo, "Perilaku Pengguna Internet Indonesia," 2017.

[3] R. Hobbs, "Improvization and strategic risk-taking in informal learning with digital media literacy," Learn. Media Technol., vol. 38, no. 2, pp. 182-197, 2013.

[4] J. T. Mgonja, A. Sirima, and P. J. Mkumbo, "A review of ecotourism in Tanzania: Magnitude, challenges, and prospects for sustainability," J. Ecotourism, vol. 14, no. 2-3, pp. 264-277, 2015.

[5] M. B. Nunez and M. A. Clores, "Environmental Literacy of K - 10 Student Completers," vol. 12, no. 5, pp. 1195-1215, 2017.

[6] S. Samto, "Literasi untuk Menghadapi Persaingan Global Abad 21," 2019, pp. 17-24.

[7] Panduan Gerakan Literasi Sekolah di Sekolah Dasar. Dirjendikmen, 2016.

[8] J. Aggleton, "Defining digital comics : a British Library perspective De fi ning digital comics : a British Library perspective," J. Graph. Nov. Comics, vol. 00, no. 00, pp. 117, 2018. 
[9] K. A. Mills and B. Exley, "Time, Space, and Text in the Elementary School Digital Writing Classroom," 2014.

[10] M. Vassilikopoulou, S. Retalis, M. Nezi, and M. Boloudakis, "Pilot use of digital educational comics in language teaching," no. May 2015, pp. 37-41.

[11] T. Richter, A. Rendigs, and C. P. Maminirina, "Conservation Messages in Speech Bubbles-Evaluation of an Environmental Education Comic Distributed in Elementary Schools in Madagascar,” pp. 8855-8880, 2015.

[12] A. N. Sutrisno and A. H. Afendi, "Penerapan Konsep Edu-Ekowisata sebagai Media Pendidikan Karakter Berbasis Lingkungan," pp. 1-11, 2018.

[13] J. Boehnert, "Ecological Literacy in Design Education: A Theoretical Introduction," Form Akad. - Res. J. Des. Des. Educ., vol. 8, no. 1, pp. 1-11, 2015. 